\title{
Antiproliferative Effect of Chloroform Extract of Cangkring Leaves (Erythrina fusca Lour.) and Its Isolates against HeLa Cells
}

\author{
Endah Puspitasari $^{1^{*}}$, Endah Dwi Setyowati ${ }^{2}$, Binar Asrining Dhiani ${ }^{3}$, \\ Sugeng Riyanto ${ }^{4}$ \\ ${ }^{1}$ Faculty of Pharmacy, Universitas Jember, Indonesia \\ ${ }^{2}$ RSUP Dr. Sardjito, Yogyakarta, Indonesia \\ ${ }^{3}$ Faculty of Pharmacy, Universitas Muhammadiyah Purwokerto, Indonesia \\ ${ }^{4}$ Faculty of Pharmacy, Universitas Gadjah Mada, Yogyakarta, Indonesia
}

\begin{abstract}
Cervical cancer is a type of cancer possessing the $3^{\text {rd }}$ highest incidence among women worldwide. Today's therapies against cancer are still ineffective, thus people are seeking for alternative method. Erythrina fusca Lour. has been used traditionally as anticancer. This experiment is conducted to study the ability of chloroform extract of E. fusca Lour. leaves and its isolates on HeLa cervical cancer cells. The cytotoxicity assay and doubling time assay were done using direct counting method, while the DNA staining assay was done using acrydine orange. The chloroform extract and isolate \# 30 showed cytotoxic activity with $\mathrm{IC}_{50}$ of 16 and $5 \mu \mathrm{g} / \mathrm{ml}$, respectively, while isolate \# 2 and isolate \# 8 didn't. The effluent \# 30 could not affect HeLa cells growth at the given concentration, but it might promote DNA fragmentation indicating apoptosis induction. The molecular mechanisms underlying these effects still need to be further explored.
\end{abstract}

Keywords: Erythrina fusca Lour., isolate and effluent of chloroform extract, antiproliferative, cervical cancer

\section{INTRODUCTION}

Cervical cancer arises as a type of cancer possessing the $3^{\text {rd }}$ highest incidence among women worldwide (WHO/ICO, 2010). Cancer therapies used today, including chemotherapy, surgery, and radiotherapy, are causing many side effects (Redd, et al., 2001). Thus, researchers are still looking for alternative medicine. The unlimited sources for medicine comes from nature (Koehn and Carter, 2005). One of the cancer remedies used traditionally for cancer is Erythrina fusca Lour. (Duke, 1983). Scientific evidence of this remedy as anticancer are still being developed.

Previous researches revealed that the protein isolated from E. fusca Lour. leaves showed cytotoxic activity on HeLa cells with $\mathrm{IC}_{50}$ of $2 \mu \mathrm{g} / \mathrm{mL}$ (Julia, 2001), while ethanolic extract of leaves, bark, and seed of this plant also exhibited cytotoxic properties on HeLa cells with $\mathrm{IC}_{50}$ of 14,11 (Meiyanto, et al.,
2003), and $1 \mu \mathrm{g} / \mathrm{mL}$ (Afiyati, 2002), respectively. The antiproliferative effect of those extracts might be related to their effect on cell cycle arrest, thus the cells' doubling time were longer (Meiyanto, et al., 2003). The fact that methanolic extract of the leaves did not toxic on Wistar male rat and did not cause any toxic symptoms based on acute toxicity test has made this plant promising to be developed as anticancer. This research is aimed to determine the antiproliferative effect of chloroform extract of the E. fusca Lour. leaves and its isolates.

\footnotetext{
*Corresponding author email: puspitasarisetiawan@gmail.com
} 


\section{MATERIALS AND METHODS}

\section{Chemicals}

Chloroform extract of E. fusca Lour. leaves and its isolates (\#2, \#8, and effluent \#30) were obtained from Cancer Chemoprevention Research Center (CCRC) Faculty of Pharmacy, UGM. The choloform extract contains terpenoid, flavonoid, and phenolic compounds. Isolates \#2 and \#8 contains hydrocarbon compounds, while effluent \#30 has phenolic and flavonoid compounds (CCRC unpublished data, 2004). Acrydin orange and dimethyl sulfoxide were purchased from Sigma.

\section{Cell Lines and Treatment}

HeLa cervical cancer cells were the collection of CCRC. The cells were a gift from Prof. Kawaichi, Nara Institute of Science and Technology (NAIST), Japan. HeLa cells were cultured in culture medium consisting RPMI 1640 (Sigma) supplemented with 10\% Fetal Bovine Serum (FBS) (Gibco), 10,000 units $/ \mathrm{mL}$ penicillin-10,000 $\mu \mathrm{g} / \mathrm{ml}$ streptomycin (Gibco) at $37^{\circ} \mathrm{C}$ in humidified $5 \% \mathrm{CO}_{2}$ in tissue culture flask (Nunclon).

\section{Cytotoxicity Assay}

Cytotoxicity assay by direct counting was done to examine the effect of choroform extract of E. fusca Lour. leaves and its isolates on $\mathrm{HeLa}$ cell line. HeLa cells $(10,000$ cells/well) were distributed into 96-well plate (Nunclon) and incubated with various concentration of samples for $24 \mathrm{~h}$. At the end of incubation time, cells were resuspended, then viable cells were counted manually under inverted microscope (Olympus) using haemocytometer (Nebauer).

\section{Doubling Time Assay}

The most potent sample based on cytotoxicity assay was then used in doubling time assay and DNA staining assay. HeLa cells were maintained using RPMI 1640 supplemented with $0.5 \%$ FBS for $24 \mathrm{~h}$. Then, they were spread $(15,000$ cells/well) into 96well plate (Nunclon) and incubated with a series of concentration of sample in culture medium below $\mathrm{IC}_{50}$. Sampling was done at 6 , $12,24,48$, and $72 \mathrm{~h}$. The incubation time were plotted vs viable cells. The doubling time was counted from the slope of the curve (Field, et al., 1996).

\section{DNA Staining Assay}

Coverslips (Iwaki) were placed in 24well plates (Nunclon). Then 15,000 HeLa cells were seeded along with a series of concentration of samples below $\mathrm{IC}_{50}$ for $48 \mathrm{~h}$. At the end of incubation time, culture medium were replaced with acrydin orange and ethidium bromide solution (for 2 minutes incubation at room temperature each). Then, cover slips were put onto object glass and analyzed under fluorescence microscope (Olympus).

\section{Analysis}

Cytotoxicity assay. Probit analysis on concentration vs $\%$ cell viability was used to calculate the $\mathrm{IC}_{50}$, the concentration inhibiting $50 \%$ of cell proliferation.

Doubling time assay. The viable cells of the specified time among treatments were compared using student $\mathrm{t}$ test. The doubling time was counted based on the slope of linear regression from incubation time vs log cell viability (Field, et al., 1996).

DNA staining assay. Qualitative analysis was done to compare the DNA morphology of each treatment with acrydin orange under fluorescence microscope.

\section{RESULTS AND DISCUSSION}

Cytotoxicity assay of chloroform extract of E. fusca Lour. leaves was done as initial screening of nature-based chemopreventive agent for cancer, especially on cervical cancer. The positive results gained from this research will be used for determining the cytotoxic compound of E. fusca Lour.

Cytotoxicity assay was done by direct counting assay under inverted microscope. Viable cells looked like leaves, give brilliant shine, and membrane boundary is clearly observed. While death cells were unglowing, have roundedshape and ruptured cell membrane (Fig. 1). DMSO as co-solvent did not show any cytotoxic effect on $24 \mathrm{~h}$ incubation (Fig. 1). But chloroform extract and effluent \# 30 gave cytotoxicity effect with $\mathrm{IC}_{50}$ of 16 and $5 \mu \mathrm{g} / \mathrm{mL}$, respectively (Fig. 2).

Based on cytotoxicity assay, effluent \# 30 was then chosen for doubling time assay. Effluent \# 30 at given concentration $(3.91 ; 1.95$; and $0.98 \mu \mathrm{g} / \mathrm{mL}$ ) did not affect HeLa cells' growth (Fig. 3 and Table I). But it caused DNA fragmentation on HeLa cells based on DNA 

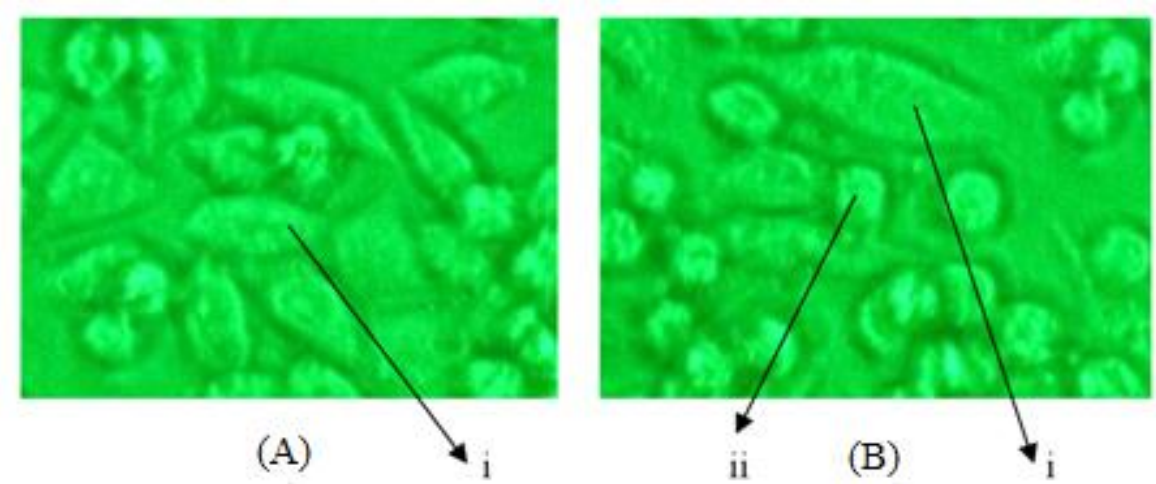

Figure I.HeLa cells morphology resulting from cytotoxicity assay (viewed by using inverted microscope, mag. 945x). Viable cells (i) are dominating on untreated well (a), while death cells (ii) were found on treated well (b).
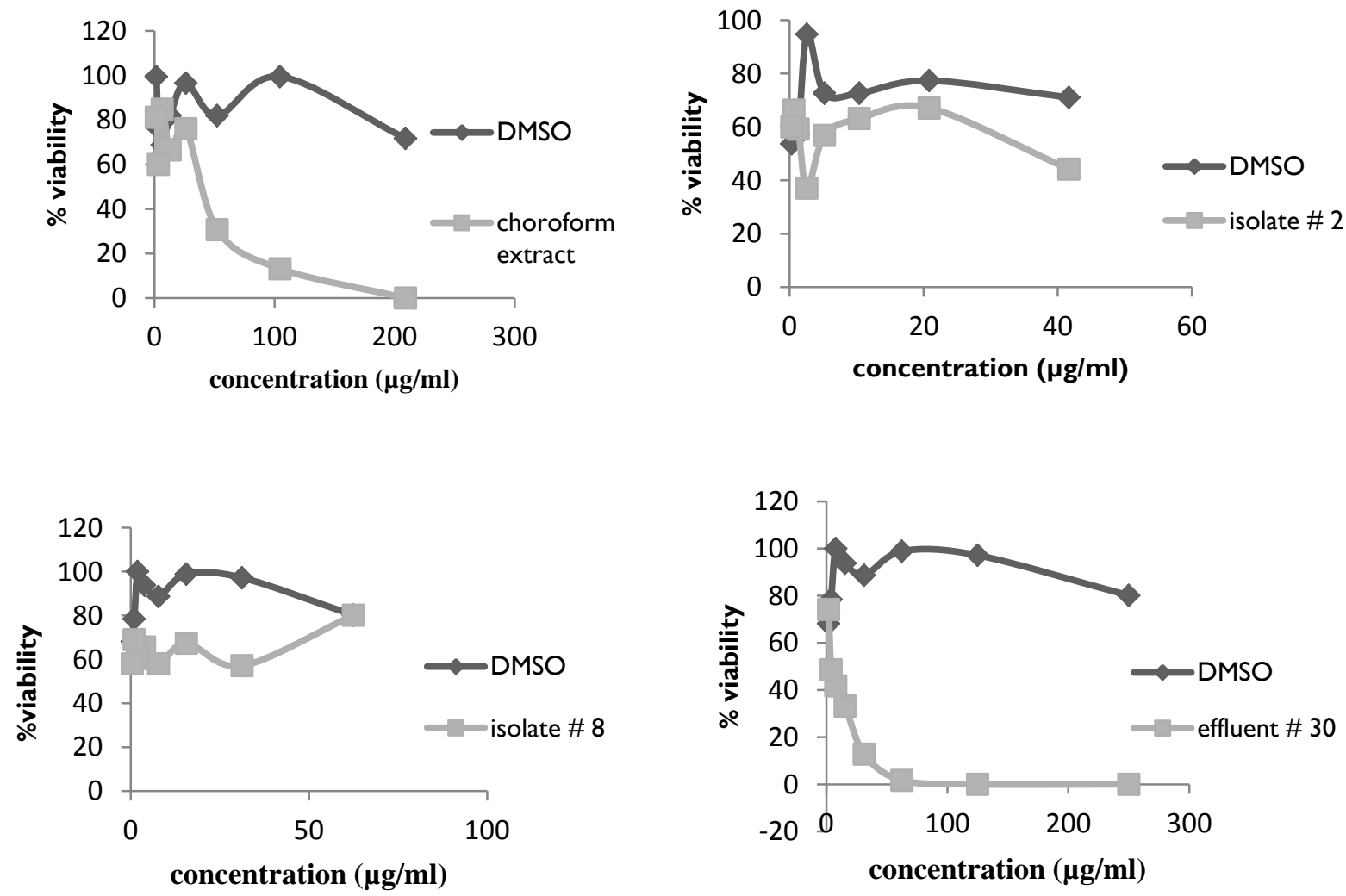

Figure 2. HeLa cells' viability upon cytotoxicity assay. HeLa cells with density $\left(3 \times 10^{3}\right)$ were treated by chloroform extract, isolate \#2, isolate \#8, and isolate \#30, then incubated for 24 hours. Cells viability were obtained from the conversion of absorbance values of formazan that formed by MTT treatment as described in the procedure of research. $I C_{50}$ were obtained from probit analysis of cell viability vs concentration 


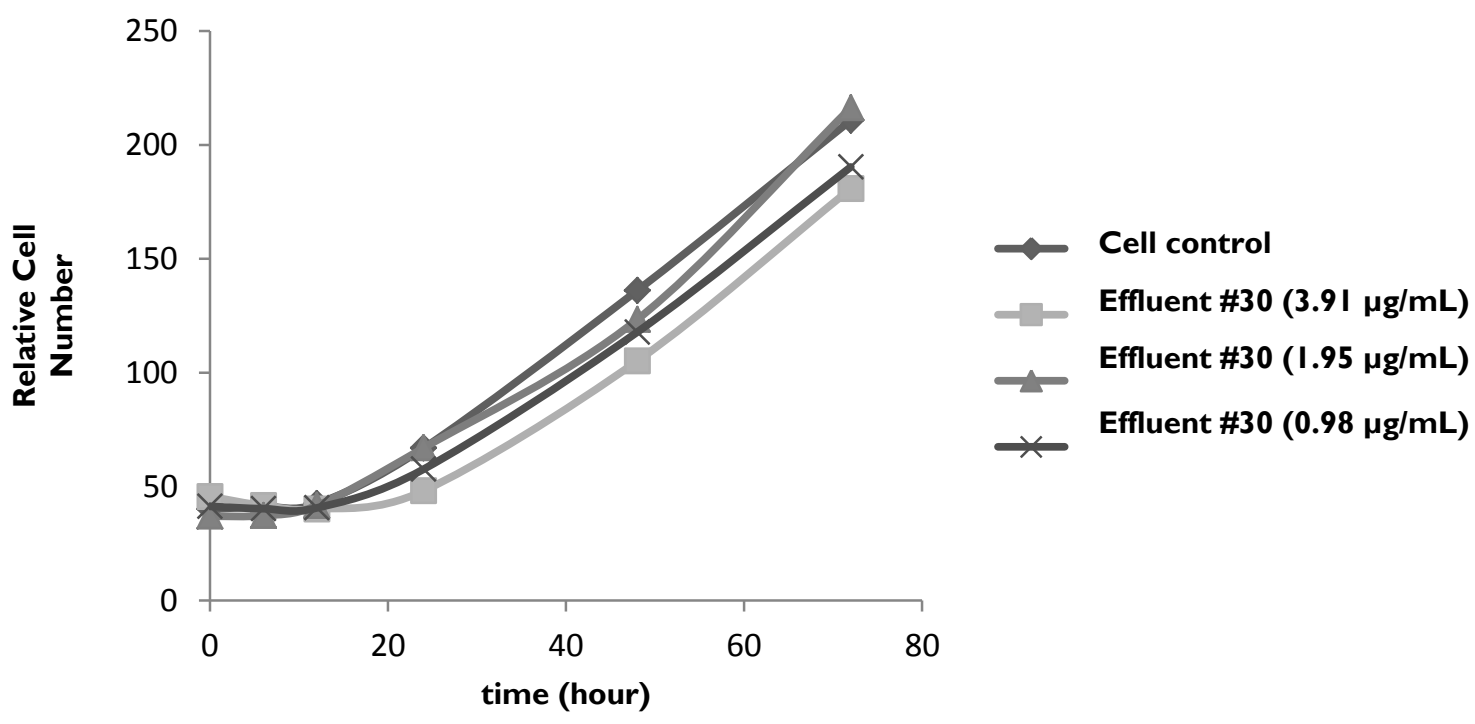

Figure 3. Effect of chloroform fractions on HeLa cells growth at the time series. Cells were growth at initial concentration below IC 50 of each compound and subjected for MTT assay at time series of $6,12,24,48$, and $72 \mathrm{~h}$.

Table I. Doubling time result

\begin{tabular}{lc}
\hline \multicolumn{1}{c}{ Treatment } & $\begin{array}{c}\text { Doubling } \\
\text { time(hours) }\end{array}$ \\
\hline Cell control & 25.9 \\
Effluent \# 30 $(3.91 \mu \mathrm{g} / \mathrm{mL})$ & 26.4 \\
Effluent \# $30(1.95 \mu \mathrm{g} / \mathrm{mL})$ & 25.7 \\
Effluent \# $30(0.98 \mu \mathrm{g} / \mathrm{mL})$ & 26.6 \\
\hline
\end{tabular}
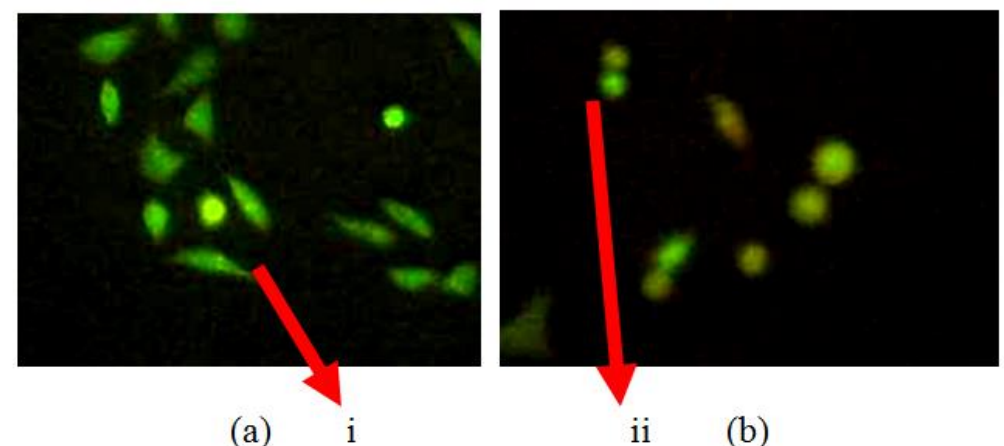

Figure 4.Morphological observation on HeLa cells' DNA based on DNA staining with acrydin orange and ethidium bromide as described in the methods (viewed under fluorescence microscope, mag. 400x), on cell control (a) and treated cell (b). Cell control was dominated by viable cell (i), while apoptotic body (ii) were dominating treated cells.

Chloroform extract of E. fusca Lour. leaves and isolate \# 30 showed potential cytotoxic activity since the $\mathrm{IC}_{50}$ were less than $100 \mu \mathrm{g} / \mathrm{mL}$ (Prayong, et al., 2008). Isolate \# 30 itself showed stronger cytotoxic activity than chloroform extract. Based on TLC screening, chloroform extract contains terpenoid, flavonoid, and phenolic compounds, while isolate \# 30 contains flavonoid and phenolic compounds (CCRC unpublished data, 2004). At the same concentration, the flavonoid and phenolic content in isolate \# 30 is higher than chloroform extract. Flavonoids have been known to exhibit anticancer activity (Chahar, et al., 2011). It might be an explanation how the isolate \# 30 gave stronger effect. But, which flavonoid or phenolic compound contributes 
more to the cytotoxic effect of isolate \# 30 still needs to be explored further.

Doubling time assay showed that effluent \# 30 did not affect HeLa cells' growth at a given concentrations. This phenomenon might be due to insufficiency of active substance contributing to cytotoxic effect. To determine the exact cause, doubling time assay using higher concentration and longer exposure time need to be done.

The DNA staining assay showed that effluent \# 30 might promote apoptosis on HeLa cells. The DNA fluoresence of treated cells looked fragmented, while the control cells still looked like its former shape. Apoptotic cells will undergo DNA fragmentation (Di Filippo and Bernardi, 2009). The effluent \# 30 cause fragmented cells maybe due to apoptotic body formation.

There are several possibilities of molecular mechanisms of flavonoid, phenolic compounds, and other compounds contained in effluent \# 30 in promoting apoptosis on HeLa cells. First, they up regulatep53 gene. $p 53$ is a tumor suppressor gene being responsible in inhibiting cell proliferation once DNA is disrupted, meaning that it promotes $\mathrm{G}_{1}$ arrest. It also induces apoptosis if the cell could not repair its decay (Bai and Zhu, 2006).

The second mechanism is by maintaining p53 and pRb activity. Those proteins are in normal state in HeLa cells, but they were degraded by E6 and E7 of HPV (Desaintes, $e t$ al., 1999). The compounds in effluent \# 30 might inhibit p53 and pRb degradation, so those proteins would normally functioned and cell cycle will be normal again.

The third possibility is by inhibiting telomerase. Telomerase works by continues extension of telomer resulting in immortal cell. Telomerase is expressed higher in cancer cells compared to normal cells (Armanios and Greider, 2005). E6 and E7 of HPV that infect $\mathrm{HeLa}$ cells induce c-myc. Therefore, it promotes telomerase and causes cell immortality (Desaintes, et al., 1999). The compounds found in effluent \# 30 might inhibit E6 and E7 activation, causing telomerase inhibitor and cell will die.

The fourth possibility is by modulation of cell cycle regulators. Flavonoids have been proved to induce $\mathrm{p} 21$ and $\mathrm{p} 27$ expression, and inhibit Cdk2 and Cdk4 (Roy, et al., 2007). CIP/KIP proteins are proteins that induce $\mathrm{G}_{1}$ arrest and promote cells in $S$ phase to enter $G_{2}$ phase by forming trimer complex with Cdk-cyc. While Cdk is positive regulator of cell cycle (Mallumbres and Barbacid, 2009). When Cdk is inhibited, cell cycle would be arrested. Those possibilities of molecular mechanisms,along with another possible mechanisms that mediate HeLa cells growth inhibition by effluent \# 30 need to be explored further. As the conclusion, chloroform extract of E. fusca Lour. leaves and effluent \# 30 exhibited cytotoxic activity with $\mathrm{IC}_{50}$ of 16 and $5 \mu \mathrm{g} / \mathrm{mL}$, respectively, while isolate \# 2 and isolate \# 8 did not show any cytotoxic effect on HeLa cells. Effluent \# 30 could not affect HeLa cells' growth at given concentration, but it promoted DNA fragmentation resulted from apoptosis induction.

\section{ACKNOWLEDGEMENT}

This work was supported by research grant of Competitive Research Grant, from Direktorat Jenderal Pendidikan Tinggi Republik Indonesia, 2004.

\section{REFERENCES}

Afiyati, R., 2002, Efek Antiproliferatif Ekstrak Etanol Biji Tanaman Cangkring (Erythrina fusca Lour.) terhadap Sel HeLa, Skripsi, Fakultas Farmasi Universitas Gadjah Mada, Yogyakarta, 56-64

Armanios, M. and Greider, C.W., 2005, Telomerase and Cancer Stem Cells, Cold Spring Harb Symp Quant Biol, 70, 205-208

Bai, L. and Zhu, W.G., 2006, p53: Structure, Function, and Therapeutic Applications, Journal of Cancer Molecules, 2(4), I4I-I53

Chahar, M.K., Sharma, N., Dobhal, M.P., and Joshi, Y.C., 20II, Flavonoids: a Versatile Source of Anticancer Drugs, Pharmacogn Rev, 5(9), I-12

Desaintes, C., Goyat, S., Garbay, S., Yaniv, M., and Thierney, F., 1999, Papillomavirus E2 Induces p53-Independent Apoptosis in HeLa Cells, Oncogene, I 8, 45834545

Di Filippo, M. and Bernardi, G., 2009, The Early Apoptotic DNA Fragmentation Targets a Small Number of Specific Open Chromation Regions, PloS ONE, 4(4), e50 I0 
Duke, J.A., 1983, Erythrina fusca Lour., Handbook of Energy Crops, http://www.hort.purdue.edu/newcrop/ duke_energy/Erythrina_fusca.html, accessed March 20th, 20I3

Field, S.J., Tsai, F.Y., Kuo, F., Zubiaga, A.M., Kaelin, Jr.W.G., Livingston, D.M., Orkin, S.H., and Groenberg, M.E., 1996, E2F Functions in Mice to Promote Apoptosis and Suppress Proliferation, Cell, 85, 549-56I

Julia, S., 200I, Uji Sitotoksisitas Fraksi Protein Daun Erythrina fusca Lour. (Cangkring) pada Sel HeLa, Skripsi, Fakultas Farmasi Universitas Gadjah Mada, Yogyakarta, 6, 65

Koehn, F.K. and Carter, G.T., 2005, Rediscovering Natural Products as a Source of New Drugs, Discovery Medicine, 5(26), I59-164

Mallumbres, M. and Barbacid, M., 2009, Cell Cycle, CDKs and Cancer: a Changing Paradigm, Nat Rev Cancer, 9(3), I53166

Meiyanto, E., Sismindari, Candra, L., and Moordiani, 2003, Efek Antiproliferatif Ekstrak Etanol Daun dan Kulit Batang Tanaman Cangkring (Erythrina fusca Lour.) terhadap Sel HeLa, Indonesian Journal of Pharmacy, I4(3), I24-131
Prayong, P., Barusrux, S., and Weerapreeyakul, N., 2008, Cytotoxic Screening of Some Indigenous Thai Plants, Fitoterapia, 79, 598-60I

Redd, W.H., Montgomery, G.H., and DuHamel, K.N., 200I, Behavioral Intervention for Cancer Treatment Side Effects, J Natl Cancer Inst, 93, 810-823

Roy, S., Kaur, M., Agarwal, C., Tecklenburg, M., Sclafani, R.A., and Agarwal, R., 2007, P2I and p27 Induction by Silibinin is Essensial for Its Cell Cycle Arrest Effect in Prostate Carcinoma Cells, Mol Cancer Ther., 6, 2696-2707

Sismindari, Yuswanto, A.G., Susanti, L., and Ngolady, D., 200I, Effects of Aqueous and Methanol Extract of Erythrina fusca Lour. on DNA Topoisomerase II, J. of Biotechnology, I 2, 48।-487

WHO/ICO, 2010, Information Centre on HPV and Cervical Cancer (HPV Information Centre), Human Papilomavirus and Related Cancers in World, Summary Report 2010, http://apps.who.int/ hpvcentre/statistics/dynamic/ico/Summ aryReportsSelect.cfm, accessed on March 20th, 20II. 